\title{
Service Quality of Traditional and Islamic Commercial Banks in Bangladesh \\ Shohel Rana ${ }^{1}$ and Imran Ahmed Shakeer ${ }^{2}$
}

\begin{abstract}
Purpose: This study aims to know the service quality of the different private commercial banks operating in Bangladesh with the rapid advancement in information technology and provide some guidelines to improve their service qualities.

Methodology: The study used both primary and secondary data to support the objective. Primary data were collected from 240 customers, of whom 120 customers are from traditional private commercial banks and the rest from private Islamic commercial banks operating in Bangladesh using a structured interview schedule, naming SERVQUAL. The study used a convenience sampling method to select respondents. Secondary data were collected from different journals, newspaper articles, books, and various published sources. An independent samples t-test was conducted in the test of the hypothesis.

Findings: This study found a significant difference between the traditional and Islamic commercial banks' service quality and added that the study area's customers/clients are not fully satisfied with either traditional private commercial banks or Islamic banks. However, Islamic commercial banks are showing a relatively better picture.

Research Limitations: The Study is limited to Bangladesh's small marginal market and a small sample size of only 240 respondents, which cannot sufficiently reflect the large population's actual scenario.

Practical Implications: The Study will help manage the traditional and Islamic commercial banks and policymakers to improve their service quality and improve monitoring efficiency.

Originality/value: The Study extensively identified some factors to improve the traditional and Islamic commercial banks' service quality for both the banks' and policymakers' management. In this regard, the critical factors can be the number of employees and the number of counters, increasing ATM services, ensuring faster services, flexible loan disbursement policy, sufficient floor space, suitable sitting arrangements, and improved online services.
\end{abstract}

Keywords: Service Quality, Traditional banking, Islamic banking, SERVQUAL.

\section{Introduction}

To ensure the mobilization of available funds and make the funds accessible and guide them to be allocated inefficient economic activities, any market economy requires a banking system. The banking system plays a vital role in channeling funds from those who have a surplus after consumption to those who have more productive uses. Banks provide financial services to reduce the cost of transferring funds from lenders to borrowers, leading to a more efficient allocation of resources and faster economic growth. Thus, banks have been essential elements of a modern economy, not only in turnover, but also as the national economy's primary financier (Allen et al., 2012). According to the Bank Company Act-1991, a bank is a financial institution that borrows money and lends or advances money either upon or without security and conducts other banking activities. Among different types of banks, only commercial banks can offer a current account. All the commercial banks are operated under the Bank Company Act-1991. On the other hand, "Islamic bank" is a particular type of banking company licensed by Bangladesh Bank that follows Islamic Shari'ah in all its principles. Islamic banks avoid receiving or paying interest in any form at all levels (Bangladesh Bank, 2009). It may seem that Islamic banks' functioning is like other traditional banks as they receive deposits from their customers and lend money from the deposits collected like traditional banks, but are different in their procedures and methods of collecting deposits and sanctioning loans. They follow the Islamic Shari'ah and avoid any form of interest strictly prohibited in Shari'ah (Othman and Owen, 2001). Recently, Islamic banking has been a very accessible alternative to traditional banking services. So, the

\footnotetext{
${ }^{1}$ Associate Professor, Dept. of Finance and Banking, Jatiya Kabi Kazi Nazrul Islam University, Trishal, Mymensingh-2220, E-mail: s.rana_fb@yahoo.com

${ }^{2}$ Lecturer, Department of Business Administration, Ishakha International University, Bangladesh. 461, Nilgonj Road, Sholakia, Kishoreganj2300, E-mail: imranahmedshakeer@gmail.com.
} 
competition in the banking industry has increased to a great extent. To successfully compete in this trendy competitive atmosphere, the pursuit of service quality is considered to be an essential strategy. Islamic banking industries have performed remarkably in the banking sector over the last few decades. Global Islamic financial services grew up at 10\%-15\% during 1995-2005 (Khan et al., 2008). Many non-Muslims banking consumers now prefer Islamic banking to traditional banking for superiority in providing banking services. Many renowned traditional banks are now opening Islamic banking wings to provide interest-free services widely to respond to the increased demand for Islamic banking services (Hasan \& Ahmed, 2001). So, service quality is the ultimate weapon in the current banking competition to increase market share. In the service industry, service quality is regarded as an overall price. Service quality depends on the gap between the expectation of the customers and the service delivered. Parasuraman et al., (1988) identified in their study that it is difficult for the customers to evaluate service quality than product quality. They also argued that service quality is not dependent only upon the service results, but also on the process of service delivery. Marketers always need to think from the customers' point of view about service quality. To attract consumers, marketers conduct extensive research to get ideas about customers' perception of their service quality. They use the research result to improve the service quality according to the expectation of the customers. However, it is more difficult to give an objective quality evaluation in service as the user has fewer tangible elements than evaluating a product. Again, globalization and tremendous advancement in information technology have forced companies to focus on customer relationships, especially customer satisfaction and customer loyalty, to maximize revenues. Service quality is considered an essential strategy for the business's success and survival in a competitive environment. Though service quality is necessary, there is no general agreement for measuring the concept. Most researchers depend on the SERVQUAL methodology (Parasuraman et al., 1985; 1988) to measure service quality. The most used models for measuring service quality and comparing customers' expectations with the actual service delivery. The method has five generic dimensions, which are stated below:

Tangibility: Tangibility defines the appearance of the physical facilities and surroundings, the equipment, personnel, and of course, the way of communication. The tangible dimension creates the first-hand impression that the customers get and may relate to the bank.

Reliability: Reliability defines the bank's ability to perform and complete the promised service, quality, accurate, and timely. Reliability is just as crucial as the first-hand impression. Every customer wants to know that their bank can be reliable and give the service agreed, including excellent quality within the given timeframe.

Responsiveness: Responsiveness defines the bank's willingness to help its customers and provide them with a good, fast, and quality service. Like all the other dimensions, responsiveness is also vital. Without a doubt, the customers will feel valued customers and get the best quality service possible.

Assurance: Assurance defines the bank employees that they are skilled workers who can trust and confidence.

The employees must be able to give the customers assurance in the services they are trying to sell. If the company is coming or current clients are not comfortable or feel safe dealing with the employees, they are likely not to continue doing business with the bank. Assurance is a lot about keeping and maintaining business relations.

Empathy: Empathy defines a bank that cares and gives individualized attention to its customers to feel special and valued as a customer. The fifth dimension, empathy, combines the reliability, responsiveness, and assurance to a higher level, yet they are still comparable, as they are all individual dimensions of the service quality mix. It is imperative to give customers individualized and quality attention. The more unique and valued they feel, the higher the chances are for them to return to the bank and continue doing business. The SERVQUAL method is used throughout the study.

\section{Objectives of the Study}

- To compare the services of the traditional and Islami bank from the perspective of quality. 
Business Review- A Journal of Business Administration Discipline, Khulna University, Volume: 14, Number: 1, January-June 2019, pp.7-16 (Print ISSN: 1811-3788; Online ISSN: 2664-3502)

\section{Literature Review}

Service quality is termed as the gap between customers' expectations and a service's real performance (Parasuraman et al., 1985; 1988). Parasuraman et al. (1988) developed the SERVQUAL model to identify five dimensions: tangibility, responsiveness, reliability, assurance, and empathy. The customers' prioritized "Responsiveness" is an essential service quality dimension, followed by tangibility, reliability, commitment, and kindness, respectively (Afrin, 2012). The banking consumers now prefer Islamic Banking to traditional banking beside their superior customer value and satisfaction and fulfill the growing demand for products and services. Islamic banking excellent quality service and excellent customer responses are required by strict compliance to Islamic Shariah and satisfactory community service through job creation and consistent service provisions (Mahmood \& Osman, 2015). Consumers prefer Islamic banking products and services consciously for profitability and religious principles (Bashir, 2013). The Shariah-based Islamic banking system competing with the traditional banking system has gained popularity among the banking stakeholders. The satisfaction level of the Islamic banks' customers is significantly higher than the traditional bank customers in terms of maintenance of confidentiality by the bank, confidence in the bank's management, the behavior of employees, provision of Islamic products and services, compliance with Islamic Shariah, the convenience of branch locations, the convenience of working hours, access to current banking related information, cleanliness of the banking environment, and overall interior comfort of branches (Mamun \& Khan, 2014).

Islamic banks are less cost-effective but have a higher mediation ratio, higher asset quality, better capitalization, and less mediate crises (Beck et al., 2012). Sarker et al. (2015) added that Shariah-based banking became popular as it expanded its modern financial markets activities. Despite difficulties in measuring banks' service quality, customer perceptions suggest that the service standard has not improved the whole banking industry's growth. Due to the vast advancement in information technology, the volume of transactions improved, and increased customer expectation; it is still a vogue practice with document-based banking. Moreover, among retail banking, credit, and international trade departments, service quality substantially improved only in the retail banking department (Roy, 2018). Personal attention to the clients, maintaining error-free documentation, ensuring safety in transactions, and having tangible physical facilities is considered the most critical service quality factor (Islam \& Ahmed, 2005). Service quality and affordable service charge positively impact customer satisfaction in a mass service industry (i.e., banking industry) and indirectly influences customer satisfaction through the perceived value (Uddin \& Akhter, 2012). Most Muslim customers chose the Islamic bank from the religious perspective rather than the bank features such as location and profit. Shariah-based principles consider the single most crucial factor for selecting Islamic banks (Naser et al., 1999). All the above studies conducted in different countries deal with the common problem. Most of them were conducted to analyze the service quality of Islamic and Traditional Banks. All reviews do not explore the same result because of differences in selected periods, analytical tools, and cultural perspectives. Business nature, technological change, business dimension, the country's economic system, economic growth, and the related factors are changed after passing the time. Due to the changing condition of time (Mostly technological change) is demanding the new study in the field of service, quality of traditional and Islamic Commercial Banks operating in Bangladesh.

\section{Rationality of the Study}

The study will help enrich the existing stock of knowledge about the banking industry's service quality, especially private traditional commercial banks, and Islamic banks. Through the study result, the banks' management will know their relative strengths and weaknesses in providing digital banking services. It will get an outline of exercising their powers and overcoming their weaknesses. Again, this study will significantly help the researchers to identify different study areas. Finally, through this study, the banking industry, policymakers will identify the focal points to improve the overall banking industry's service quality and adopt appropriate policies for ensuring a smooth banking environment in the economy.

\section{Methodology of the Study}

In the study, researchers mainly used primary data for analysis collected using a structured interview schedule, naming SERVQUAL from Bangladesh, especially from Greater Mymensingh, the marginal market economy (i.e., 
Mymensingh, Tangail, Netrokona, Sherpur, Kishoregonj, Jamalpur) retail banking. Secondary data were collected from different journals, newspaper articles, books, and various published sources. The sample size is 240 , out of which 120 from traditional banks' customers, and the rests are from Islamic banks' customers; for sampling, researchers used a convenience sampling method.

For data analysis, the researchers conducted SERVQUAL and a two-tailed t-test. In SERVQUAL, researchers analyzed through Tangibility, Reliability, Responsiveness, Assurance, Empathy to determine the scale's item and factorial structure and assess its reliability and validity. For each service quality dimension above, SERVQUAL measures both the service's expectation and perception on a scale from 1 to 7 of 22 questions in total. Then, the five dimensions, weight to customers' importance, and the score for dimension is multiplied by their weight. Following this, each dimension's gap score is calculated by subtracting the expected score from the perception score. A negative gap score indicates that the actual service (the perceived score) was less than expected (the expectation score), whereas a positive gap score indicates the vice-versa. For statistical analysis, researchers conducted an independent samples t-test at 0.05 level of significance with the following hypothesis.

Null Hypothesis: There is no significant difference between the mean gap scores of perceived and expected traditional and Islamic commercial banks' service quality.

Alternative Hypothesis: There is a significant difference between the mean gap scores of perceived and expected traditional and Islamic commercial banks' service quality.

\section{Data Analysis and Findings \\ SERVQUAL analysis}

\section{Tangibility}

Table-1: Average Expectation, Perception, and Gap Score of Traditional and Islamic Banks from Statement 1 to Statement 4.

\begin{tabular}{|c|c|c|c|c|c|c|c|}
\hline \multirow[t]{2}{*}{ Statement } & \multirow{2}{*}{$\begin{array}{l}\text { Description of the } \\
\text { statement }\end{array}$} & \multicolumn{3}{|c|}{ Traditional Banks } & \multicolumn{3}{|c|}{ Islamic Banks } \\
\hline & & Expectation & Perception & $\begin{array}{l}\text { Gap } \\
\text { Score }\end{array}$ & Expectation & Perception & $\begin{array}{c}\text { Gap } \\
\text { Score }\end{array}$ \\
\hline 1 & $\begin{array}{l}\text { The bank has modern } \\
\text { looking equipment }\end{array}$ & 6.91 & 5.91 & -1.00 & 6.84 & 5.91 & -0.93 \\
\hline 2 & $\begin{array}{l}\text { The bank's physical } \\
\text { features are visually } \\
\text { appealing }\end{array}$ & 6.44 & 5.44 & -1.00 & 6.44 & 5.40 & -1.04 \\
\hline 3 & $\begin{array}{l}\text { The bank's receptions } \\
\text { desk employees are neat } \\
\text { appearing }\end{array}$ & 6.77 & 6.19 & -0.58 & 6.68 & 6.37 & -0.31 \\
\hline 4 & $\begin{array}{l}\text { Materials associated } \\
\text { with the service are } \\
\text { visually appealing and } \\
\text { practical at the bank }\end{array}$ & 6.71 & 5.89 & -0.82 & 6.74 & 6.08 & -0.66 \\
\hline & Average & 6.71 & 5.86 & -0.85 & 6.68 & 6.08 & -0.59 \\
\hline
\end{tabular}

Source: Computed data

The table- 1 showed the tangibility of services provided by traditional and Islamic banks in the selected region. The four statements are considered as the measure for tangibility. Traditional banks have an average expected score of 6.71, where the customers' average perception score is 5.86, with a negative gap score of 0.85 .

This is clearly showing that customers of traditional banks are not getting their expected tangible services. The same scenario is for Islamic banks, but their average gap score (-0.59) is lower than that of traditional banks (-0.85). So, in the case of providing tangible services, Islamic banks are performing better than traditional banks. 
Business Review- A Journal of Business Administration Discipline, Khulna University, Volume: 14, Number: 1, January-June 2019, pp.7-16 (Print ISSN: 1811-3788; Online ISSN: 2664-3502)

\section{Reliability}

Table-2: Average Expectation, Perception, and Gap Score of Traditional and Islamic Banks from Statement 5 to Statement 9.

\begin{tabular}{|c|c|c|c|c|c|c|c|}
\hline \multirow{2}{*}{$\begin{array}{l}\text { State } \\
\text { ment }\end{array}$} & \multirow[t]{2}{*}{ Description of the statement } & \multicolumn{3}{|c|}{ Traditional Banks } & \multicolumn{3}{|c|}{ Islamic Banks } \\
\hline & & $\begin{array}{l}\text { Expectat } \\
\text { ion }\end{array}$ & $\begin{array}{l}\text { Percept } \\
\text { ion }\end{array}$ & $\begin{array}{l}\text { Gap } \\
\text { Score }\end{array}$ & $\begin{array}{c}\text { Expecta } \\
\text { tion }\end{array}$ & $\begin{array}{l}\text { Percep } \\
\text { tion }\end{array}$ & $\begin{array}{l}\text { Gap } \\
\text { Score }\end{array}$ \\
\hline 5 & $\begin{array}{l}\text { When the bank promises to do something } \\
\text { by a specific time, it does so }\end{array}$ & 6.71 & 6.13 & -0.57 & 6.77 & 6.23 & -0.54 \\
\hline 6 & $\begin{array}{l}\text { When you have a problem, the bank shows } \\
\text { a sincere interest in solving it }\end{array}$ & 6.73 & 5.62 & -1.12 & 6.73 & 5.88 & -0.86 \\
\hline 7 & $\begin{array}{l}\text { The bank performs the right services at } \\
\text { first. }\end{array}$ & 6.69 & 5.64 & -1.05 & 6.63 & 5.62 & -1.02 \\
\hline 8 & $\begin{array}{l}\text { The bank provides its services at the time it } \\
\text { promises to do so. }\end{array}$ & 6.59 & 5.62 & -0.98 & 6.68 & 5.97 & -0.71 \\
\hline 9 & The bank insists on error-free records & 6.62 & 6.07 & -0.55 & 6.66 & 6.23 & -0.43 \\
\hline & Average & 6.67 & 5.82 & -0.85 & 6.69 & 5.99 & -0.71 \\
\hline
\end{tabular}

Source: Computed data

Table-2 showed a comparison of customers' satisfaction with reliable services provided by traditional and nontraditional Islamic banks. Above mentioned five statements had been considered as the measure of the reliability of providing services. Customers' average SERVQUAL expectation score for reliable services is very close to both banks; 6.67 for traditional banks and 6.69 for Islamic banks. However, customers' average perception score is higher in the case of Islamic banks. Moreover, Islamic banks have a gap score of -0.71, whereas traditional banks have a gap score of -0.85 . This lower gap score shows a lower deviation bet the average expectation and perception score. In this sense, Islamic banks are performing better than traditional banks in case of providing reliable services.

Responsiveness : Measure the banks' employees' responsiveness; four statements took into consideration. In each of the comments, both types of banks showed negative gap scores between average perception and expectation score. Their gap scores are -1.25 and -0.94 for traditional and Islamic banks, respectively, which measures less deviation of perception scores of expectation score. It also clarifies that employees of Islamic banks are more responsive than the employees of traditional banks.

Table-3: Average Expectation, Perception, and Gap Score of Traditional and Islamic Banks from Statement 10 to Statement 13.

\begin{tabular}{|c|c|c|c|c|c|c|c|}
\hline \multirow{2}{*}{$\begin{array}{c}\text { Stat } \\
\text { eme } \\
\text { nt }\end{array}$} & \multirow[t]{2}{*}{ Description of the statement } & \multicolumn{3}{|c|}{ Traditional Banks } & \multicolumn{3}{|c|}{ Islamic Banks } \\
\hline & & Expectation & Perception & $\begin{array}{c}\text { Gap } \\
\text { Score }\end{array}$ & Expectation & Perception & $\begin{array}{c}\text { Gap } \\
\text { Score }\end{array}$ \\
\hline 10 & $\begin{array}{l}\text { Employees tell customers exactly when } \\
\text { the services will be performed }\end{array}$ & 6.73 & 5.45 & -1.28 & 6.69 & 5.68 & -1.01 \\
\hline 11 & Employees provide prompt service & 6.65 & 5.50 & -1.15 & 6.78 & 5.83 & -0.94 \\
\hline 12 & Employees are willing to help customers & 6.72 & 5.58 & -1.13 & 6.72 & 5.65 & -1.07 \\
\hline & Average & 6.63 & 5.38 & -1.25 & 6.65 & 5.71 & -0.94 \\
\hline
\end{tabular}

Source: Computed data 
Business Review- A Journal of Business Administration Discipline, Khulna University, Volume: 14, Number: 1, January-June 2019, pp.7-16 (Print ISSN: 1811-3788; Online ISSN: 2664-3502)

\section{Assurance}

Table-4: Average Expectation, Perception, and Gap score of Traditional and Islamic Banks from Statement 14 to Statement 17.

\begin{tabular}{|c|l|c|c|c|c|c|c|}
\hline $\begin{array}{c}\text { Stat } \\
\text { eme } \\
\text { nt }\end{array}$ & \multicolumn{2}{|c|}{ Description of the statement } & \multicolumn{3}{c|}{ Traditional Banks } & \multicolumn{3}{c|}{ Islamic Banks } \\
\cline { 2 - 7 } & $\begin{array}{c}\text { Expectat } \\
\text { ion }\end{array}$ & $\begin{array}{c}\text { Percept } \\
\text { ion }\end{array}$ & $\begin{array}{c}\text { Gap } \\
\text { Score }\end{array}$ & $\begin{array}{c}\text { Expectat } \\
\text { ion }\end{array}$ & $\begin{array}{c}\text { Percep } \\
\text { tion }\end{array}$ & $\begin{array}{c}\text { Gap } \\
\text { Score }\end{array}$ \\
\hline 14 & $\begin{array}{l}\text { The behaviors of employees instill } \\
\text { confidence in customers }\end{array}$ & 6.63 & 5.55 & -1.08 & 6.61 & 5.70 & -0.91 \\
\hline 15 & $\begin{array}{l}\text { Customers feel safe while making } \\
\text { transactions with the bank }\end{array}$ & 6.74 & 6.13 & -0.62 & 6.67 & 6.35 & -0.32 \\
\hline 16 & Employees are consistently courteous & 6.82 & 5.86 & -0.96 & 6.74 & 6.11 & -0.63 \\
\hline 17 & $\begin{array}{l}\text { Employees know to answer customer's } \\
\text { questions }\end{array}$ & 6.75 & 5.89 & -0.86 & 6.74 & 6.11 & -0.63 \\
\hline \multicolumn{1}{|c|}{ Average } & $\mathbf{6 . 7 4}$ & $\mathbf{5 . 8 6}$ & $\mathbf{- 0 . 8 8}$ & $\mathbf{6 . 6 9}$ & $\mathbf{6 . 0 7}$ & $\mathbf{- 0 . 6 2}$ \\
\hline
\end{tabular}

Source: Computed data

Assuring customers that the bank is providing the right services to its customers is another measure of customer satisfaction. Customers have an average expected score of 6.74 in traditional banks and 6.69 in Islamic banks. Customers are expecting more assurance from traditional banks. However, the survey shows that traditional banks failed in this regard as they have an average perception score of 5.86. In contrast, an Islamic bank has a perception score of 6.07 , which is reflected by their gap score of -0.88 and -0.62 by the traditional banks and Islamic banks, respectively. It means that the Islamic banks are providing more assurance to their customers while providing the right services.

Empathy : Empathy means the capacity, the understanding, and the feelings of another person within their frame. Table-5 shows that customers are expecting that Islamic banks will be more empathetic, rendering quality services. Customers' average expectation score is 6.61 for Islamic banks and 6.47 for traditional banks. However, like other parameters, traditional banks failed to show empathy to their customers.

Table-5: Average Expectation, Perception, and Gap score of Traditional and Islamic Banks from Statement 18 to Statement 22.

\begin{tabular}{|c|c|c|c|c|c|c|c|}
\hline \multirow{2}{*}{$\begin{array}{c}\text { Stat } \\
\text { eme } \\
\text { nt }\end{array}$} & \multirow[t]{2}{*}{ Description of the statement } & \multicolumn{3}{|c|}{ Traditional Banks } & \multicolumn{3}{|c|}{ Islamic Banks } \\
\hline & & $\begin{array}{l}\text { Expectat } \\
\text { ion }\end{array}$ & $\begin{array}{l}\text { Percept } \\
\text { ion }\end{array}$ & $\begin{array}{c}\text { Gap } \\
\text { Score }\end{array}$ & $\begin{array}{l}\text { Expectati } \\
\text { on }\end{array}$ & $\begin{array}{l}\text { Percept } \\
\text { ion }\end{array}$ & $\begin{array}{l}\text { Gap } \\
\text { Score }\end{array}$ \\
\hline 18 & The bank gives customers individual attention & 6.41 & 4.66 & -1.75 & 6.51 & 5.39 & -1.12 \\
\hline 20 & $\begin{array}{l}\text { Employees give the customers personal } \\
\text { attention }\end{array}$ & 6.07 & 4.48 & -1.59 & 6.30 & 4.95 & -1.35 \\
\hline 22 & Employees understand specific needs & 6.84 & 6.17 & -0.67 & 6.93 & 6.36 & -0.57 \\
\hline & Average & 6.47 & 5.22 & -1.25 & 6.61 & 5.58 & -1.03 \\
\hline
\end{tabular}

Source: computed data

Customers are dissatisfied and perceive a lower average score of 5.22, while Islamic banks have an average perception score of 5.58. On the other hand, the average gap score for traditional banks is -1.25 and -1.03 for Islamic banks, which indicates that Islamic banks are more empathetic in providing quality services to their customers. 
Business Review- A Journal of Business Administration Discipline, Khulna University, Volume: 14, Number: 1, January-June 2019, pp.7-16 (Print ISSN: 1811-3788; Online ISSN: 2664-3502)

Table-6: Factor-Wise Average Scores (Un-weighted and Weighted) for Traditional Banks

\begin{tabular}{|l|c|c|c|c|c|}
\hline \multicolumn{1}{|c|}{ Factor } & Expectation & Perception & UWAGS & Weight & WAGS \\
\hline Tangibility & 6.71 & 5.86 & -0.85 & 25.00 & -21.20 \\
\hline Reliability & 6.67 & 5.82 & -0.85 & 25.00 & -21.33 \\
\hline Responsiveness & 6.63 & 5.38 & -1.25 & 20.00 & -25.04 \\
\hline Assurance & 6.74 & 5.86 & -0.88 & 15.00 & -13.19 \\
\hline Empathy & 6.47 & 5.22 & -1.25 & 15.00 & -18.79 \\
\hline
\end{tabular}

Table-7: Factor-Wise Average Scores (Un-weighted and Weighted) for Islamic Banks

\begin{tabular}{|l|c|c|c|c|c|}
\hline \multicolumn{1}{|c|}{ Factor } & Expectation & Perception & UWAGC & Weight & WAGS \\
\hline Tangibility & 6.68 & 6.08 & -0.59 & 25.00 & -14.79 \\
\hline Reliability & 6.68 & 6.08 & -0.59 & 25.00 & -14.79 \\
\hline Responsiveness & 6.65 & 5.71 & -0.94 & 20.00 & -18.78 \\
\hline Assurance & 6.69 & 6.07 & -0.62 & 15.00 & -9.34 \\
\hline Empathy & 6.61 & 5.58 & -1.03 & 15.00 & -15.42 \\
\hline
\end{tabular}

Lower the gap between the average perception and expectation scores, the customers are more satisfied. Islamic banks have lower gap scores in each factor that proves that Islamic banks provide tangible, reliable, responsive, assured, and empathetic services to their customers. Hence, customers of Islamic banks are more satisfied than the customers of traditional banks.

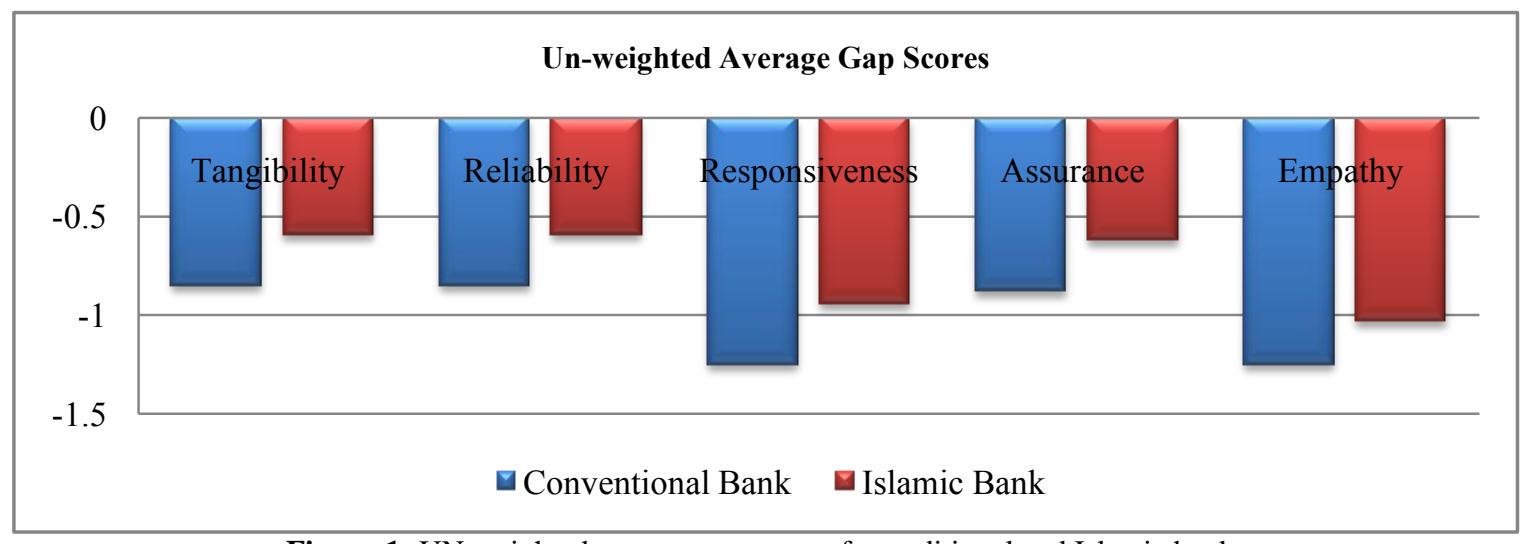

Figure-1: UN-weighted average gap scores for traditional and Islamic banks

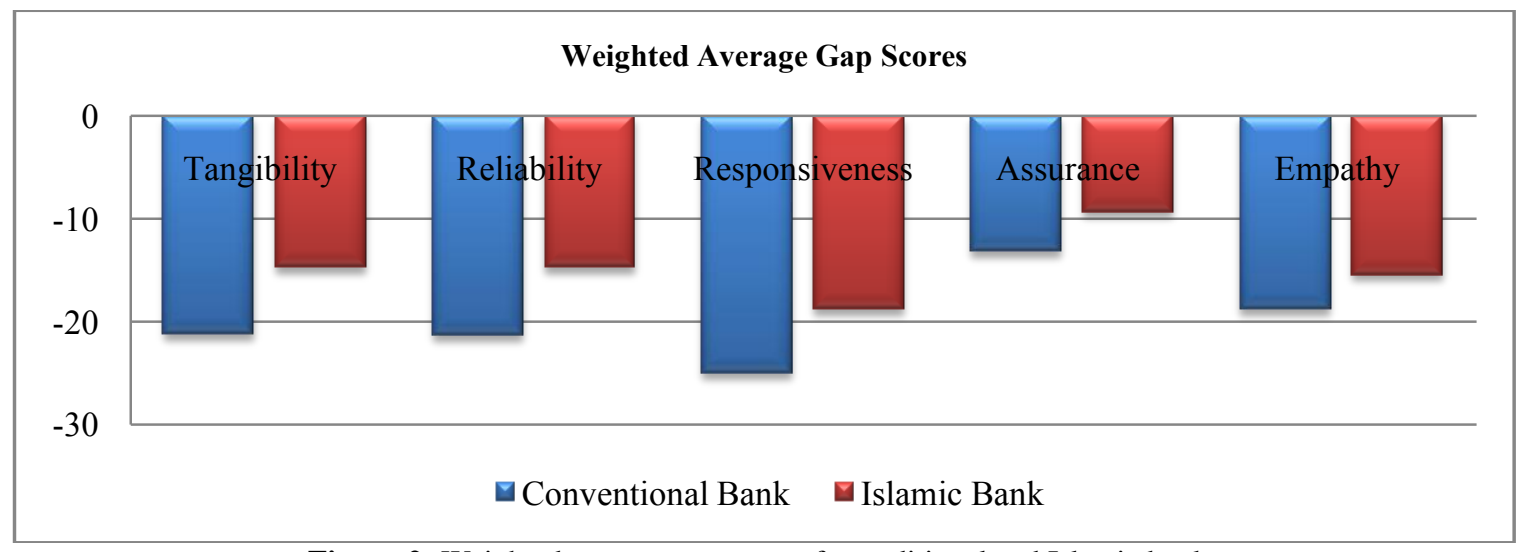

Figure-2: Weighted average gap scores for traditional and Islamic banks 
Figure-2 explained the weighted average gap scores for traditional and Islamic banks. In this study, tangibility, reliability, responsiveness, assurance, and empathy are given weights of 25, 25, 20, 15, and 15, respectively. As Islamic banks were ahead of all the parameters in unweighted average gap scores, they are also showing better performance than weighted-average gap scores. So, it is very much clear that customers of Islamic banks are more satisfied with the services provided by their banks than the customers of traditional banks.

\section{Key SERVQUAL findings}

The tangibility of Services: Tangibility considers the physical appearance of the banks, personnel, equipment the banks use, and communication materials. The study found that Islamic banks provide more tangible banking services to their customers than traditional banks do. The traditional commercial banks have a negative gap score of -0.85. But in the case of Islamic banks, their average gap score (-0.59). Again, traditional banks are lagging in all the criteria of providing tangible services. Islamic banks are ahead in case of tangibility.

Reliability: Reliability of services measures banks' ability to provide promised service dependably and accurately. The study comparing the five statements of reliability showed that Islamic and traditional banks provide reliable services; the extent is more significant in Islamic banks. Because Islamic banks have a gap score of -0.71 , traditional banks have a gap score of -0.85 .

Responsiveness: Responsiveness takes the willingness of employees to help customers get superior services into consideration. Measure the responsiveness of the employees of the banks; four statements take into consideration. In each of the comments, both types of banks showed negative gap scores between average perception and expectation score. Their gap scores are -1.25 and -0.94 for traditional and Islamic banks, respectively, which measures less deviation of perception scores of expectation score.

Assurance: Assurance considers courtesy and knowledge of employees and their capability to ensure confidence and trust in customers' minds. Since the gap score of traditional commercial banks and Islamic banks is - 0.88 and 0.62 , respectively. This study found that Islamic banks ensure their customers in providing trusted and secure services than the traditional counterpart.

Empathy: Empathy focuses on care and attention to customers while providing efficient banking services. Islamic banks have more SERVQUAL average perception scores in all the empathy statements. In this case, the average gap score for traditional banks is -1.25 and -1.03 for Islamic banks, which indicates that Islamic banks are more empathetic in providing quality services to their customers.

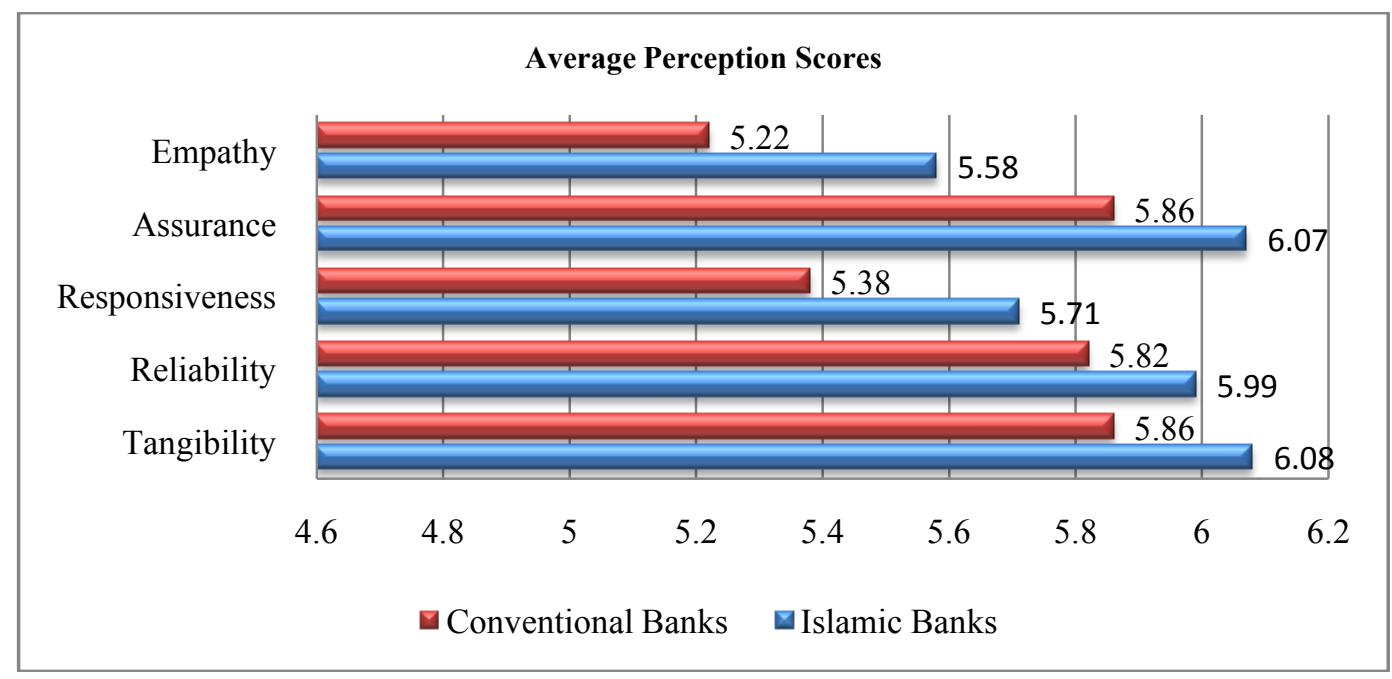

Figure-3: Comparison of Islamic banks and traditional banks based on average perception scores. 
Finally, this study found that the customers/clients in this area are not fully satisfied with the service quality of either traditional private commercial banks or Islamic banks. Still, the Islamic commercial Banks are holding a relatively better picture.

\section{T-test}

Null Hypothesis: there is no significant difference between the mean gap scores of perceived and expected service qualities of the traditional and Islamic banks,

$$
H_{0}: \mu_{1}=\mu_{2}
$$

Alternative Hypothesis: There is a significant difference between the mean gap scores of perceived and expected service qualities of the traditional and Islamic banks,

$$
H_{1}: \mu_{1} \neq \mu_{2}
$$

$\mu_{1}=$ Mean gap scores of 22 SERVQUAL statements of conventional banks

$\mu_{2}=$ Mean gap scores of 22 SERVQUAL statements of Islamic banks

Table 1: T-test Results

\begin{tabular}{|c|c|c|c|c|c|c|c|c|c|c|}
\hline \multicolumn{11}{|c|}{ Independent Samples Test } \\
\hline & & \multicolumn{2}{|c|}{$\begin{array}{c}\text { Levene's Test } \\
\text { for Equality of } \\
\text { Variances }\end{array}$} & \multicolumn{7}{|c|}{ t-test for Equality of Means } \\
\hline & & \multirow[t]{2}{*}{$\mathrm{F}$} & \multirow[t]{2}{*}{ Sig. } & \multirow[t]{2}{*}{$\mathrm{t}$} & \multirow[t]{2}{*}{ df } & \multirow[t]{2}{*}{$\begin{array}{l}\text { Sig. } \\
(2- \\
\text { tailed })\end{array}$} & \multirow[t]{2}{*}{$\begin{array}{c}\text { Mean } \\
\text { Difference }\end{array}$} & \multirow[t]{2}{*}{$\begin{array}{l}\text { Std. Error } \\
\text { Difference }\end{array}$} & \multicolumn{2}{|c|}{$\begin{array}{l}\text { 95\% Confidence } \\
\text { Interval of the } \\
\text { Difference }\end{array}$} \\
\hline & & & & & & & & & Lower & Upper \\
\hline \multirow[t]{2}{*}{ Value } & $\begin{array}{c}\text { Equal } \\
\text { variances } \\
\text { assumed }\end{array}$ & 0.002 & 0.961 & -2.272 & 42 & 0.028 & -0.20682 & 0.09103 & -0.39052 & -0.02312 \\
\hline & $\begin{array}{c}\text { Equal } \\
\text { variances } \\
\text { not } \\
\text { assumed }\end{array}$ & & & -2.272 & 41.264 & 0.028 & -0.20682 & 0.09103 & -0.39061 & -0.02302 \\
\hline
\end{tabular}

\begin{tabular}{|c|c|c|c|c|c|}
\hline \multicolumn{7}{|c|}{ Group Statistics } \\
\hline \multirow{2}{*}{ Value } & S1=0, S2=1 & N & Mean & Std. Deviation & Std. Error Mean \\
\cline { 2 - 6 } & S1 & 22 & -1.0205 & .32143 & .06853 \\
\hline
\end{tabular}

The computed significance value of the t-test 0.028 says that only at a $2.8 \%$ level of confidence and the gap scores are not significantly different. In contrast, the set level of significance is 0.05 . Researchers rejected the null hypothesis that there is no significant difference between the mean gap scores of perceived and expected service qualities of the traditional and Islamic banks based on the computed significance value. They accepted the alternative hypothesis that there is a significant difference between the mean gap scores of the traditional and Islamic banks' perceived and expected service quality.

\section{Concluding Remarks}

Service quality is the primary tool for a sustainable banking business and will create superior values for the banks' stakeholders. Private Banks have performed very well since their inception. Among private banks, there are nontraditional Islamic banks and traditional commercial banks. Both are trying to improve their customer service quality. However, both have been failing to provide the customers with the expected services. This study finally revealed that Islamic banks are more successful in delivering quality services than private traditional commercial banks. 
Business Review- A Journal of Business Administration Discipline, Khulna University, Volume: 14, Number: 1, January-June 2019, pp.7-16 (Print ISSN: 1811-3788; Online ISSN: 2664-3502)

\section{References}

Afrin, T. (2012), "Quality of customer service in Bangladesh's banking sector: An explorative study" "East-West Journal of Business and Social Studies, Vol. 3, pp. 68-94.

Allen, F. \& Carletti, E. (2012), "The role of banks in financial systems," Oxford Handbook of Banking, DOI: 10.1093/oxford he/9780199640935.013.0002

Bangladesh Bank (2009), "Guidelines for conduction Islamic banking,” Bangladesh Bank: November 2009.

Bashir, M. S. (2013), "Analysis of customer satisfaction with the Islamic banking sector: The case of Brunei Darussalam,"Asian Journal of Business and Management Sciences, Vol. 2, No. 10, pp. 38-50.

Beck, T.,Domirguc-Kunt, A. and Merrouche, O. (2012),"Islamic vs traditional banking: business model, efficiency and stability,"Journal of Banking \& Finance, Vol. 37, pp. 433-447.

Hassan, M. K., and Ahmed, M. (2001), "Islamic versus traditional banking: A survey of their apparent similarities and differences,"International Journal of Bank Marketing, Vol. 28, No. 6, pp. 14-19.

Islam, N. and Ahmed, E. (2005), "A measurement of customer service, quality of banks in Dhaka City of Bangladesh,"South Asian Journal of Management, Vol. 2, No. 1, pp. 37-57.

Khan, N.S.M., Hassan, K.M. and Shahid, I.A. (2008), "Banking behaviour of Islamic bank customers in Bangladesh,"Journal of Islamic Economics, Banking and Finance, Vol. 3 No. 2, pp. 159-194.

Mahmood, S. M. \& Osman, W. (2015), "Customers' perception of service, quality of Islamic bank in Bangladesh: An empirical analysis of Shahjalal Islami Bank Limited," Global Journal of Management and Business Research: Administration and Management, Vol. 15, No. 12, pp. 1-18.

Mamun, M. Z. and Khan, R.H. (2014), "Customers' satisfaction of Islamic banking and traditional banking in Bangladesh: A comparative study,” Journal of Business Studies, Vol. 35, No. 1, pp. 85-103.

Naser, K., Jamal, A. and Al-Khatib, K. (1999),"Islamic banking: A study of customer satisfaction and preferences in Jordan," International Journal of Bank Marketing, Vol. 17 No. 3, pp.135-150.

Othman, A. and Owen, L. (2001), “Adopting and measuring customer service quality (SQ) in Islamic banks: A case study in Kuwait Finance House," International Journal of Islamic Financial Service, Vol. 3, No. 1, pp. 126.

Parasuraman, A.Zeithaml, V. A. and Berry, L. L. (1994), "Reassessment of expectations as a comparison in measuring service quality: Implications for further research,"Journal of Marketing, Vol. 58, No. 1, pp. 111124.

Parasuraman, A., Zeithaml, V. A. and Berry, L. L. (1988),"SERVQUAL: A multiple-item scale for measuring consumer perceptions of service quality," Journal of Retailing, Vol. 64, No. 1, pp. 12-40.

Roy, N. (2018), "Maintaining the quality of banking services," The Financial Express, June 08, 2018 [Available at https://thefinancialexpress.com.bd/views/maintaining-quality-of-banking-services-1528210972,accessed on May 24, 2019].

Uddin, M. and Akhter, B. (2012), "Determinants of customer satisfaction in the banking industry in Bangladesh," Pak. J. Comer Soc. SCI., Vol. 6, No. 2, pp. 242-256. 